\title{
分子動力学法による半導体中の欠陥の拡散挙動解析 \\ Diffusion mechanism analysis of point defects in semiconductors by molecular dynamics
}

\author{
$\bigcirc^{1}$ 柿本浩一（九州大応力研） ${ }^{2}$ 野口真一郎（九州大総理工） 正 ${ }^{3}$ 尾添紘之（九州大機能研） \\ Koichi KAKIMOTO, Shin-ichiro NOGUCHI, Hiroyuki OZOE \\ 1 RIAM, Kyushu University, 6-1, Kasuga-Koen, Kasuga, 816-8580, Fukuoka \\ 2 IGSES, Kyushu University, 6-1, Kasuga-Koen, Kasuga, 816-8580, Fukuoka \\ 3 IAMS, Kyushu University, 6-1, Kasuga-Koen, Kasuga, 816-8580, Fukuoka

\begin{abstract}
This paper aims to study diffusion mechanism of point defects such as vacancies and interstitials of silicon in silicon-germanium solid solution using molecular dynamics simulation. Moreover, equilibrium volume of the silicon, germanium and these alloys were also estimated by using two different schemes of constant volume. The calculation revealed that diffusion constants of the point defects are almost independent of external pressure. Furthermore, volume of the system changed almost isotropically.
\end{abstract}

Key Words: Molecular dynamics, Silicon, Germanium, Point defects

\section{1. はじめに}

半導体中の点欠陥は、その凝集体の形成により半導体結 晶中に空洞欠陥を形成する。このために、高精度の電子デ バイス形成には、半導体中の点欠陥の形成過程および移動 過程を精密に制御する必要がある。一般に、半導体の結晶 成長は融液の固化により行われるために、固液界面近傍の 温度は高くなる。このような環境下では、点欠宿の挔散過 程を実験的に観測することはほとんど不可能であり、数值 計算による推定が必要となってくる。

本研究では、分子動力学法を用いて代表的な半導体であ るシリコンに不純物としてゲルマニウムが混入している場 合を対象として、原子構造の変化や輸送現象の検討を行っ た。特に、シリコンーゲルマニウム固溶体中の空孔や格子 間原子の拡散過程について分子動力学法を用いて定量的な 解析を行った。

\section{2. 計算方法}

本研究では、等温等圧アルゴリズムの中で式 $(1 、 2)$ に示すような等方的なスキームであるアンデルセン法と、 異方的スキームであるパリネロ・ラーマン法の両方を用い た。

$$
\begin{aligned}
& m \frac{d^{2} \vec{r}_{i}}{d t^{2}}=-\frac{\partial \Phi}{\partial \vec{r}_{i}}-\frac{1}{3}\left(m \frac{d \vec{r}_{i}}{d t}\right)\left(\frac{1}{V} \frac{d V}{d t}\right) \\
& M \frac{d^{2} V}{d t^{2}}=\frac{1}{3 V}\left[\sum_{i=1}^{N} \frac{\vec{p}_{i}^{2}}{m}-\sum_{i=1}^{N} \vec{r}_{i} \cdot \frac{\partial \Phi}{\partial \vec{r}_{i}}\right]-P_{e x}
\end{aligned}
$$

ここで、m， $\phi, \mathrm{v}, \mathrm{t}, \mathrm{M}, \mathrm{p}, \mathrm{P}_{\mathrm{cx}}$ はそれぞれ、原子の質量、 ポテンシャルエネルギー、体積、時間、体積変化用ピスト ンの質量、運動量、外部圧力である。

計算に用いたポテンシャルは、式（3）に示すような経 験的ポテンシャルである Stillinger-Weber ポテンシャルを

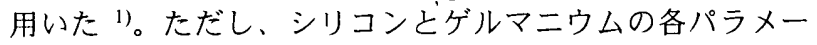
タは論文に報告されている值を用いた。また、シリコンと ゲルマニウムの間の 2 体力と 3 体力に関しては、各物質の 係数の平均值を用いて計算を行った。

$$
\Phi=\sum_{i}^{N} \sum_{i<j}^{N} \Phi_{2}\left(R_{i j}\right)+\sum_{\substack{i \\ i<j<k}}^{N} \sum_{j}^{N} \sum_{k}^{N} \Phi_{3}\left(\vec{R}_{i}, \vec{R}_{j}, \vec{R}_{k}\right)
$$

ただし、 $\mathrm{R}_{\mathrm{ij}} 、 \mathrm{R}_{\mathrm{i}} 、 \mathrm{~N}$ はそれぞれ、粒子 $\mathrm{i}$ と $\mathrm{j}$ の距離粒子、 i の位置ベクトル、粒子数である。

ここで考慮した原子の総数は 64 個であり、空孔や格子 間原子である点欠陥を含んだ場合は $63 、 65$ 個とした。 総数のうちの 1 個はゲルマニウムに膡換して、シリコンと ゲルマニウムが共存した場合における点欠陥の拡散係数の 温度依存性を求めた。このように少ない原子数を用いた理 由は、式（4，5）に示したような Einstein の関係式を用 いることにより、空孔や格子間原子である点欠陥の拡散係 数を求めるためである。すなわち、原子の拡散係数を求め るには時間 $\mathrm{t}$ を可能な限り長くするためである。

時刻 $\mathrm{t}_{0} に \mathrm{r}\left(\mathrm{t}_{0}\right)$ に存在している粒子が、拡散しながら時間 $t$ 経過した後 $r\left(t_{0}+t\right)$ に達したとすると、平均二乗変位は $\mathrm{t}$ に 比例して増大するので次のように表される。

$\left\langle\mid r(t)-r(0)^{2}\right\rangle \cong 6 D t$

すなわち D は

$D=\lim _{t \rightarrow \infty} \frac{1}{6 t}\left\langle|r(t)-r(0)|^{2}\right\rangle$

と示すことが可能である。

空孔や格子間原子である点欠陥の導入に関しては、シリ コン原子の中の 1 個を系から除去し、または 1 個の原子を 挿入することにより達成した。

\section{3. 計算結果}

$3.1 \mathrm{Si}-\mathrm{Ge}$ 固溶体体積の温度変化

図 1 は、シリコン、ゲルマニウム単体と、シリコン一ゲ ルマニウム固溶体のユニット体積の温度変化に関する計算 結果を示したものである。ここでは、アンデルセンの等圧 アルゴリズムを用いていることから、ある温度での圧力 1 気圧と平衡する体積を示している。

図から温度が上昇すると体積は増加し、密度が減少する ことがわかる。さらに、格子間原子や空孔等の点欠陥の導 入に伴う体積の変化量は、ゲルマニウム原子の格子位置へ の置換に伴う体積変化よりも大きいことがわかる。 
図 2 は、異方的スキームであるパリネロ・ラーマン法を 用いた場合の体積変化の計算值である。両方とも同じよう な変形が観測されており、格子間原子や空孔等の点欠宿や ゲルマニウムのような置換型原子が混入しても異方性のあ る変形は顕著ではないことがわかった。

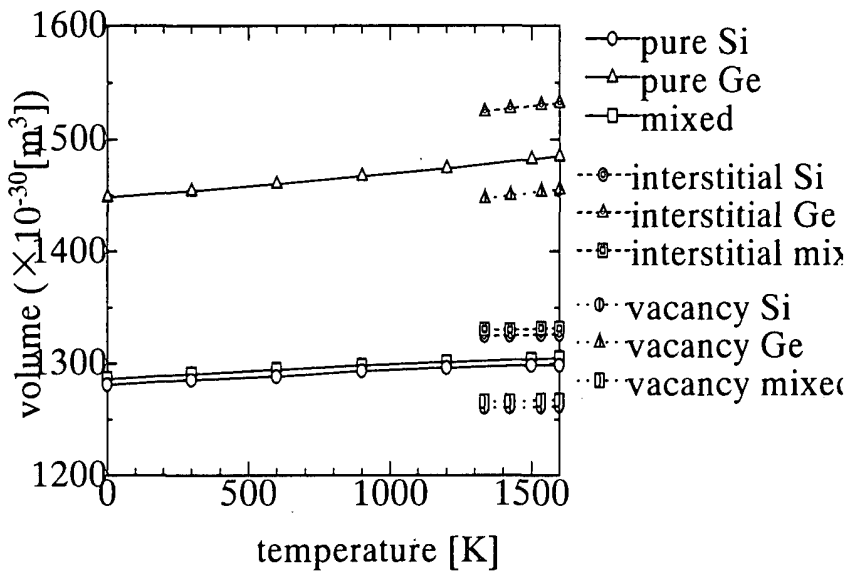

Fig. 1 Temperature dependence of calculated volume by using Andersen's method.

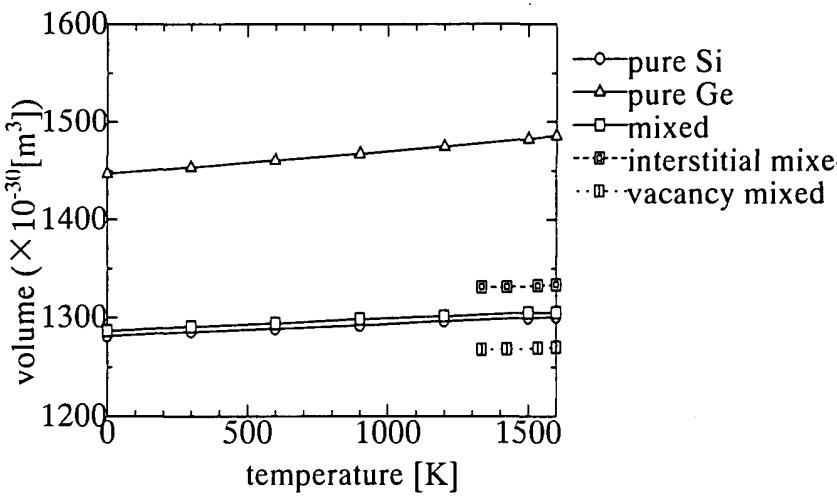

Fig. 2 Temperature dependence of calculated volume by using Pallinero Rahman's method.

図 3 は、図 1 と 2 の計算結果から得られた熱膨張係数の 温度依存性を示した。実験值は、極低温領域では值が減少 する傾向にあるが計算值はほとんど一定である。これは、 本計算では量子効果を考慮した零点振動を記述できていな いためであり、古典論的な取り扱いのみではこの零点振動 の現象の記述はできないことが明らかとなった。

\section{2 体積の圧力依存性}

図 4 は、シリコン、ゲルマニウム、シリコンーゲルマニ ウム固溶体体積の圧力依存性の計算結果を示している。こ れにより、シリコンよりもゲルマニウムのほうが圧力に対 する変化が大きいことがわかる。これは、弾性定数の大小 から推測できる結果と同じ傾向を示す。

\section{3 挔散係数の圧力依存性}

図 5 は、格子間原子の㹡散係数の圧力依存性を示す。 これにより、数千気圧の圧力下では点欠樎の拡散係数は大 きく変化しないことが明らかとなった。

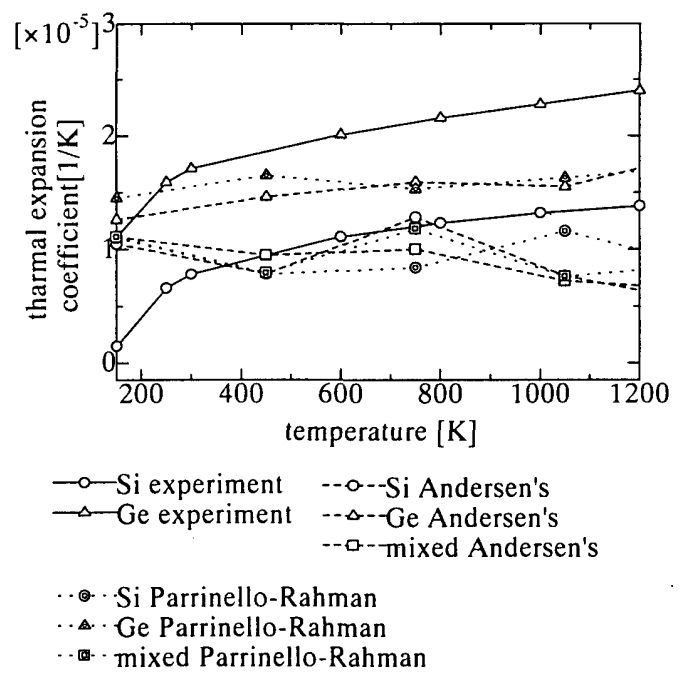

Fig. 3 Temperature dependence of thermal expansion coefficients.

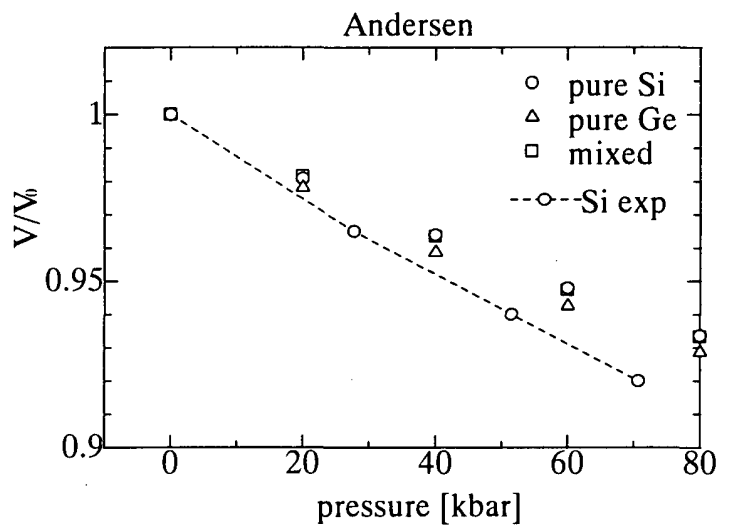

Fig. 4 Volume change as a function of external pressure.

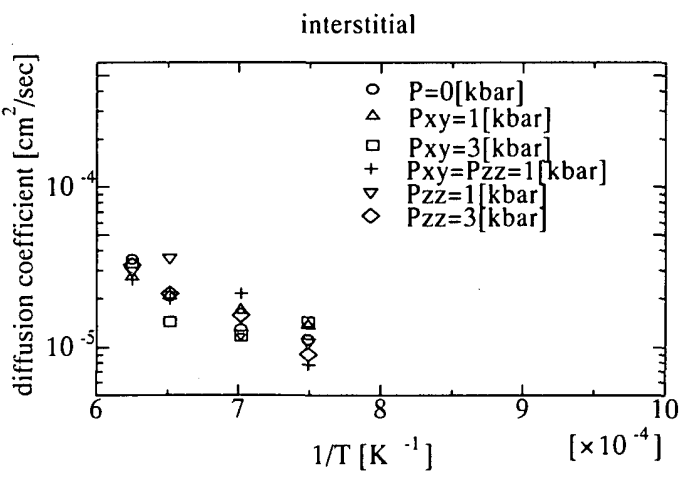

Fig.5 Diffusion coefficients of an interstitial atoms.

4. まとめ

分子動力学法により半導体の原子構造と点欠陥の移動現 象を定量的に検討した。その結果、拡散係数は圧力にはほ とんど依存しないことがわかった。

参考文献(1) F. H. Stillinger and T. A. Weber, Phys. Rev., B31, (1985) 5262. 